\title{
Vietnam
}

\section{Propaganda is not a dirty word}

\author{
Peter Mares
}

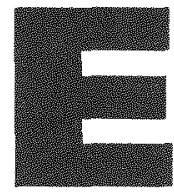

very morning in cities, towns and villages across Vietnam, people go about their business to the crackle of loudspeakers. The monotonous daily broadcasts, courtesy of the local level administration, the peoples' committee of the ward or commune, is a mix of patriotic music, official news, decrees and mundane announcements. People may be reminded not to clutter the pavement with motorcycles or ordered to be alert to the threat of 'peaceful evolution' (the coded catchphrase for attempts to undermine communist rule).

The nationwide network of around 900,000 loudspeakers dates back to Vietnam's revolutionary struggle, when party cadres would travel from village to village to proselytise, or to warn people about the latest military advance by French colonial troops. The cadres would often set up a portable loudspeaker to amplify their message. During the 'American War' a more permanent loudspeaker system was established to warn of impending raids by US B-52 bombers. At a time when few people had radios, it served as a broadcast network, providing news from the front, solace and motivation in the face of war.

These days, no one pays much attention to the loudspeakers. In some places, villagers have lobbied to get the broadcasts turned down, or turned off, or shifted to a later hour in the morning. But, mostly the broadcasts have become background noise and people just do not hear them any more. When the Communist Party held its National Congress in 1996-a landmark political event that takes place once every five years-General Secretary Do Muoi's closing speech was carried live via the network of loudspeakers strung from lampposts and trees along the streets of Hanoi. But no one bothered to stop and listen. 
The ritual of the loudspeaker neatly symbolises the Communist Party's continuing efforts to control the flow of information in Vietnam through a dogged attachment to the idea that the media is, first and foremost, a vehicle for state propaganda. On one level the strategy is a miserable failure because, like the loudspeaker broadcasts, much of the media output in Vietnam goes unheeded. There are newspapers and magazines that remain neatly folded on desks, television shows that command far less attention than the advertisements that precede them, radio programs that babble on like white noise. Much of Vietnam's media output fails to engage or entertain and the audience is often cynical about the value of the information it carries.

In a negative sense, however, the Communist Party's media strategy succeeds remarkably well. While the party may no longer be successful at generating revolutionary fervour and commitment through the media, it does efficiently circumscribe the type of news, information and ideas reaching a general audience, blocking criticism of the regime and critical debate about its policies and performance. In this sense the morning loudspeaker ritual is a daily reminder that the party's power still reaches deep into society.

\section{Colonialism to communism}

Vietnam has a long history of scholarship and learning linked to the mandarin tradition of civil service which it shares with China. In the late nineteenth century, this élite of educated Vietnamese formed the corps of the colonial administration in Indochina, but also provided the kernel of nationalist opposition to French rule.

After the turn of the century, members of this small literati began to publish newspapers and periodicals in French and Vietnamese in Saigon and Hanoi. Circulations were small, reflecting low literacy levels, and editors were constrained by censors who would quickly shut down any publication which challenged the colonial order too directly.

Nevertheless these journals were an important venue for debating nationalist ideas, including the growing conviction that it was superior knowledge and technology that enabled the Europeans to subject the Vietnamese to their colonial yoke. This reasoning led early nationalists to view education as the key to liberation. They began to push for the popularisation of the Romanised Vietnamese script quoc-ngu. Quoc-ngu 
had originally been developed by a 17th century French missionary Alexandre de Rhodes, primarily in order to aid in his own language learning and proselytising. The nationalists now adopted the script to replace the complex nom characters in which Vietnamese texts had traditionally been written and to establish Vietnamese as an acceptable language for intellectual debate. Previously classical Chinese and French were regarded as the only languages of higher learning and discourse. As publisher Phan Van Truong argued, reaching a tiny minority of Francophones was of 'very little benefit'. The aim was to produce writings on every conceivable subject so that 'all of our people are able to study' (Marr 1981:162).

By the 1930s, Vietnamese writers were experimenting with contemporary journalistic forms recently pioneered in Europe, such as investigative journalism and first person reportage (or phong $s u$ ).

One of the most celebrated examples was an expose of the suffering of Hanoi's rickshaw coolies called, I Pulled a Rickshaw. Foreign visitors to contemporary Hanoi are often charmed by the (now disappearing) cyclos, but these pedal trishaws are essentially a modern phenomena. The rickshaw coolies of the 1930s were human horses, running bare-foot between the shafts and hauling their passengers behind them. In 1932, in a deeply shocking and socially courageous act for an educated man of the time, journalist Tam Lang donned a coolie's garb and went 'undercover' to investigate the conditions of the rickshaw pullers. His florid reports were published as a series of newspaper articles.

With the friend that I met on the road, I slipped into an eating booth that was dark and as constricted as a rat's hole. I breathed in the air of fetid, choking smells. This stench was called the 'chopping board smell', but this was only partly correct, because aside from the smell of stale fat, rotten fish, tainted meat, raw onions and a hundred other kinds of food, there was, if you analysed it carefully, also the smell of excrement mingling with that of habitual sweat.

To lower a powerless person from his status as a human being to that of a horse, to give him two wooden shafts and say 'I will sit up here while you pull me' is the same as saying 'You are not a human being' (Tam Lang 1932).

Parallel to the rise of reportage in the 1930s, other writers were attempting to redress social injustice through literary realism. The novel, Impasse (Buoc Duong Cung) by Nguyen Cong Hoan, was published in 1938 
and banned soon after by the French authorities because it described how farmers struggled to pay exorbitant French taxes only to see their money squandered by a lazy, corrupt Vietnamese official.

Representative Lai's villa is located in the very centre of the village of An Dao. But his villa and the village of An Dao are two completely separate worlds... Representative Lai is frightfully rich. Other people's money, rice, paddies, and dwellings can slip into his possession with a wave of his hand (Ngo Vinh Long 1991).

Impasse is set in the northern coastal province of Thai Binh, where grievances over unfair taxes were at the heart of peasant rebellions against the French and their local collaborators-rebellions that helped give birth to Vietnam's communist revolution.

Ironically, it was in Thai Binh in 1997 that farmers echoed the complaints of their forbears. They were infuriated to see district officials constructing elaborate private homes while promised local roads remained unbuilt. A considerable portion of the farmers' precious rice harvest was consumed by a plethora of different taxes, including such arbitrary imposts as a tax on ducks crossing the road. When local officials failed to respond to peaceful demonstrations and petitions, the farmers' anger finally boiled over into violent protests. Officials' houses were burnt down and in one village some twenty policemen were taken hostage by farmers wielding sticks. But in the 1990s, under communist rule, no Vietnamese journalist or writer was able to give voice to the frustrations of the Thai Binh farmers.

In his introduction the English translation of Tam Lang's, I Pulled a Rickshaw Greg Lockhart writes that a democratic transformation in the political, social and literary consciousness during the colonial era produced 'a new way of writing' but he also notes that this type of writing 'has failed to flourish since the revolution of the 1940 s'. $^{\prime}$.

During the struggle against the French from 1945 to 1954, many journalists and writers were content to bend their pens to the service of the party and the cause of national liberation. Improvised presses were set up in the jungle, cranking out the first copies of the underground newspaper, Thang (Victory).

After the French were defeated at Dien Bien Phu in 1954 and independence was achieved in the north, journalists, artists and intellectuals began pushing for a more liberal approach during the socalled Ngan Van/Gai Pham (Humanism/Works of Beauty) movement. They were encouraged by external events such as Kruschev's 1955 denunciation 
of Stalin and by Mao's Hundred Flowers Campaign in China. But by late 1956 the party's threshold of tolerance had been reached and it reasserted control. One person who suffered was the poet/composer Van Cao, who wrote Vietnam's national anthem along with other well-known ballads that chronicle and celebrate the liberation struggle. Because of his role in the Nhan Van/Giai Pham movement Van Cao's work was no longer played in public or broadcast. The only exception was the national anthem and in the early 1980s the party even tried to find a replacement by organising a nationwide competition for alternatives.

Van Cao was rehabilitated in 1987 when another ray of light broke briefly through the oppressive clouds that hover over Vietnam's media landscape. Again influenced by developments elsewhere in the communist world, particularly Europe and the Soviet Union, party leadership relaxed controls over the media. There was a sudden re-emergence of phong su, socially engaged, critical reportage, particularly in the weekly journal Van Nghe published by the Writers Association.

But in 1989, with communism crumbling in Eastern Europe and massive pro-democracy protests erupting in China, the pendulum swung back towards control. Even though there is more apparent diversity in the media today than ten years ago, the past decade has seen a tightening of media laws and increased surveillance over journalists and editors.

One of Ho Chi Minh's first acts after declaring independence in 1945 had been to decree a nationwide campaign to stamp out illiteracy. In less than eighteen months, some 100-thousand volunteer instructors had reputedly taught more than two and a half million people to read and write.

One characteristic of the newly independent Vietnam was the barefooted peasant walking to evening classes, tiny oil lamp in one hand, battered quoc ngu primer in the other...For those who could not or would not attend evening sessions, there were special classes at the marketplace, in the rice fields, and aboard fishing boats. Study words were scrawled on the sides of buildings and train cars, and even on the mud encrusted flanks of water buffalo (Marr 1981:184).

It is a sad irony of Vietnam's communist revolution that just as the party succeeded in dramatically expanding literacy, it simultaneously set strict limits on the range of material available. In 1958 the Communist Party declared that the press was to be 'the collective agitator, propagandist and organiser, an instrument of the party to lead the masses, a sharp 
weapon in the class struggle against the enemy'. In late 1996, not much had changed - politiburo member Lt. General Le Kha Phieu (who became party chief one year later) reminded journalists that they were 'revolutionary soldiers in the field of culture ideology' and that the newspaper was 'a weapon for struggling on the political and ideological front'.

\section{Newspapers: an extensive menu serving the same dish}

At first glance, Vietnam appears to have a lively press scene, with around four hundred separate titles appearing as daily, weekly or monthly publications. They range from serious literary journals, to tabloid crime blotters; from science and technology manuals to glossy fashion magazines. The menu of newspaper choice has expanded dramatically since 1986, when the Communist Party formally endorsed the economic reform policy known as doi moi at its landmark 6th National Congress, opening the way for private enterprise to operate in many sectors of the economy. Before, the entire country had about ten newspapers, weeklies and journals owned by the central authorities and stories about sport, culture, science and social affairs had not been recognised as proper food for public thought.

In Vietnam's limited market economy, some newspapers (though not all) now have an economic incentive to attract readers. The new element of competition has helped to push out editorial boundaries. Newspapers vie to print stories of genuine interest, rather than just reams of tired ideological rhetoric or proud socialist statistics. This has had a particular impact on the coverage of popular but politically safe topics like sport. One of the big commercial success stories of recent years has been the special supplements published by Vietnam Newsagency (VNA) to coincide with international soccer tournaments such as the World Cup. The first supplements were so popular they caused major traffic jams when they hit the streets, at a time when most of the population was still riding bicycles. Officials, however, bristled, arguing that readers were not supposed to be pre-occupied with football at the cost of political awareness (Do Phoung 1997). Ten years later, however, there is an awareness within the Party of a need for more diversified, accurate information.

Advertising and competition have also had an impact on the language of journalism, though stultified, meaningless announcements are still 
common in reporting the activities of top officials. This quote from Vietnam News is typical.

General Secretary Le Kha Phieu said foreign delegations to the eighth National Confederation of Labour Congress have brought warm sentiments of friendship and solidarity to the Vietnamese people. $\mathrm{He}$ told the foreign delegations that he appreciated their organisations' valuable assistance and solidarity during Viet Nam's past struggle for national liberation and reunification and current drive for national construction and defence (7 November 1998).

This type of language still characterises such august publications as 'The central organ of the Vietnam Communist Party', the national daily Nhan Dan (The People) which proclaims on its masthead that it is "The Voice of the Party, the Government and the Vietnamese People'. The turgid language employed by Nhan Dan is shared by its military equivalent Quan Doi Nhan Dan (The People's Army) and such newspapers as Hanoi Moi (New Hanoi), published by the Hanoi branch of the Communist Party.

However, in the search for readers there has been a shift by some newspapers to employ more direct and active prose. Leading the charge are the police, with highly successful tabloids that corner the market in their own special area of expertise-stories of crime and punishment. Sidewalk vendors spruik out the juiciest story lines from Cong An Thanh Po Ho Chi Minh (Ho Chi Minh City Police), such as 'the father chopped his son into many pieces and put them in a bag...' or 'the girl wearing a thin nightdress lay under the dim lamp and the vile old man could not control himself...'

Thu, who has been selling newspapers on the same corner since the war, says that everyone reads Cong An Thanh Pho Ho Chi Minh, 'from cyclo drivers to office workers'. In 1997, the paper's weekly special edition sold 550,000 copies and its regular daily sold 100,000 copies, returning a per edition profit of about US $\$ 10,000$ in a country with an average per capita annual income of US $\$ 300$.

Nearby at police headquarters, chief editor $\mathrm{Ha}$ Phi Long denies that Cong An Thanh Pho Ho Chi Minh trades on sensationalism and scandal. He says crime stories make up just five per cent of the paper's coverage and he protests that readers do not like sensationalism. 'What they are interested in' he lectures me sternly, 'is the lessons that they can learn in order to coniribute to the authorities' efforts to ensure law and order'(1996). 
While there is little evidence to bear out his claim, it does point to the fact that for all their entertainment value, police newspapers like Cong An Thanh Pho Ho Chi Minh carry a conservative ideological message. For example, they are often at the forefront of attacks on writers and artists who dare to test the limits of cultural expression. The paper accused leading young author Pham Thi Hoai of 'insulting the Vietnamese people' when she published an innovative collection of short stories, which offered a biting satire on contemporary Vietnam and such sacred cows as the institution of the family. More recently the police newspapers directed their barbs at Vietnam's emerging new generation of pop stars, claiming various male singers were gay.

In Vietnam, all singers must audition before a panel of cultural officials and have their lyrics approved by censors before they perform in public. But this is clearly not producing the level of patriotism and skill demanded by another similar weekly, An Ninh The Gioi (Security World) 'Their money making performance has killed any creativity, many sing like machines, their voices are not rooted in their soul, they contain the smell of money' (Reuters, 27 August 1999).

As author and journalist, Robert Templer, points out in his recent book, Shadows and Wind the police tabloids glorify the Interior Ministry, the main apparatus of political repression in Vietnam, while promoting the idea that yet more social controls are needed. 'Like many tabloids, the police paper plays on the public's capacity for cognitive dissonance by sending out a very mixed message; it offers up a dystopia of rampant crime and deviancy and at the same time reassures the public that the police have got it all under control' (Templar 1998:173).

By comparison to Cong An Thanh Pho Ho Chi Minh, the party daily Nhan Dan is struggling. Officially Nhan Dan claims a circulation of more than 200,000, but the paper relies heavily on a captive audience of readers (or at least of people who receive the paper). According to Politburo instruction 11CT/TU issued in January 1997, 'each party cell, municipal peoples committee, peoples councils at district and board level and each cell of the Ho Chi Minh Communist Youth League all over the country' should have a copy of Nhan Dan. Usually the paper lies neatly folded until it is eventually collected for re-cycling. The most avid readers of Nhan Dan are foreign journalists and diplomats, who comb the arcane language for any hint of official shifts in policy or personnel within the secretive upper echelons of the Communist Party. 
Between the extremes of the police tabloids and staid party organs, a number of other newspapers have earned a degree of popular respect for their willingness to print real news and provide more thoughtful comment on a range of pressing social issues, from the abuse of factory workers to the spread of HIV-AIDS. The youth newspaper Tuoi Tre (estimated circulation 200,000) and the labour newspaper Lao Dong $(70,000)$ are good examples, though the editorial space in which they operate is strictly circumscribed.

There is no private ownership of the media in Vietnam. All newspapers and magazines are published by official organisations answerable to the Communist Party leadership. Tuoi Tre is published by the Ho Chi Minh Youth League and Lao Dong by the Confederation of Trade Unions. Both have evolved from their sectoral origins into general newspapers, and according to local journalists, Tuoi Tre at least, is a relatively profitable enterprise, operating as a semi-autonomous business and paying above average salaries in order to attract the best writers to its editorial team.

However, Tuoi Tre and Lao Dong remain on a short leash. Apart from answering to their own supervisory bodies, editors also come under scrutiny from the Ministry of Culture and Information and more importantly, from the Culture and Ideology Department of the Communist Party. No editor will ever be appointed to a newspaper without the approval of these authorities, and once in the job, editors are expected to 'drink tea' each week with department officials to ensure that they are following the correct line on key issues. Such constant monitoring ensures editorial conservatism and, as Robert Templer points out, while newspapers are now writing about official corruption they rarely initiate investigations and much of what they publish amounts to official exhortations to better behaviour.

Corruption has replaced ideological correctness as a means of overpowering opponents in political battles. Now that accusations of straying from the correct path of Marxism have no resonance, the best way of attacking a political opponent is to catch his hand in the till. Most newspaper stories on corruption or fraud are either about pervasive petty graft or they are officially approved (Templar 1998:169). Party leaders frequently encourage journalists to expose corruption, but the experiences of Nguyen Hoanh Linh prove that it is dangerous to take them at their word. Linh wrote a series of investigative articles for the business newspaper Doanh Nghiep, in which he detailed high-level 
corruption in the purchase of four patrol boats from the Ukraine by Vietnam's Customs Department. Linh was subsequently arrested and charged with revealing state secrets. After spending thirteen months in jail, he was finally brought to trial, found guilty, given a thirteen-month sentence, and released.

The party also keeps a watchful eye over foreign language magazines and newspapers published in Vietnam, such as the daily English-language Vietnam News, the Weekly Vietnam Investment Review and the monthly Vietnam Economic Times. One morning in 1996, embarrassed staff from Vietnam Investment Review were sent out door-knocking seeking the return of the latest issue of the magazine. The problem was a front-page photograph of the State Bank building in Hanoi, with a cyclist riding past in the foreground. The photograph accompanied a financial story, and in the corner was an inset of Prime Minister Vo Van Kiet. Apparently the relative size and placement of the Prime Minister's image (with the cyclist riding over his head) caused so much offence that the entire issue had to be recalled. Vietnam Investment Review also produces a weekly leisure insert called Time Out. In July 1996 the cover of a special summer edition of Time Out showed a young woman lying on a blue and white striped beach towel with a piece of green star fruit over each eye. Staff at the magazine were chastised for surreptitiously trying to reproduce the American flag.

Vietnam Investment Review is a joint venture between Vietnam's Ministry of Planning and Investment and Australian business interests, including media tycoon Kerry Packer. Former Managing Director Alex McKinnon did not deny that the magazine's links to the government set the overall editorial agenda.

'Well I don't think we are afraid to say that we are in fact, if you like, a public relations department of the Ministry of Planning and Investment' he said in an interview for $\mathrm{ABC}$ Radio. 'I mean that's why we came here, to promote Vietnam' (McKinnon 1996). Vietnam Investment Review has a resident censor from the Ministry of Culture and Information who holds the post of Deputy Editor and who in, McKinnon's words, 'monitors all the material...to make sure it is okay.'

McKinnon admitted that 'there's still an incredible amount of paranoia' when it comes to the press in Vietnam but he also says that Vietnam Investment Review's editorial team put up a solid fight to push out the boundaries of acceptable journalism. Certainly the magazine has nurtured 
some skilled, young Vietnamese journalists, although the more prominent and successful they become, the more likely they are to face professional difficulties.

Despite continuing suspicion towards domestically produced foreign language publications, government agencies also seek to use them to their own advantage, albeit rather clumsily. On 28 July 1997, Vietnam Investment Review ran the text of an exclusive interview between Reuters newsagency and politburo member Nguyen Tan Dung, a rising star within the Communist Party. In reality no interview had taken place. Reuters Hanoi office had requested an interview and submitted (as is required) a proposed list of questions. In return Reuters received written answers. Because no face-to-face interview had taken place, and because the answers were of little interest, Reuters did not file any stories based on the copy. However, some official decided to share the transcript of Dung's exclusive interview with Vietnam Investment Review, who dutifully published it in full.

\section{Radio and television: politically correct}

Despite the large number of press titles in Vietnam and the undoubted importance of the printed word to an educated urban élite, newspapers have limited relevance to the vast majority of the population who live in rural areas (except perhaps to provide convenient wrapping for food). According to a survey by Radio the Voice of Vietnam (VOV), only 8 per cent of people have regular access to newspapers in the northern provinces of Hai Hung and Ninh Binh and most are teachers, pensioners and government employees (Vietnam News, 6 October 1996). Radio is by far the most accessible medium for the 80 per cent of people who live outside Vietnam's cities and who may be literate enough to write their name, or to read signs, but who would struggle to comprehend the relatively complex language of the urban press.

The Voice of Vietnam first went to air on 7 September 1945, five days after Ho Chi Minh declared independence. During the following nine years of nationalist war against the French, The Voice of Vietnam's rudimentary transmitters were constantly relocated to different points in Vietnam's rugged northern mountains. As a symbol of that struggle, the Voice of Vietnam broadcasts still begin with the original signature tune Smashing Fascism. 


\section{Losing control}

Today The Voice of Vietnam transmissions reach more than 80 per cent of the country, with five domestic channels (including a channel broadcasting in minority languages such as Khmer and $\mathrm{H}^{\prime} \mathrm{Mong}$ ) and a network of 53 local radio stations throughout the country. The Voice of Vietnam also has an international shortwave service broadcasting in eleven languages. There are no private radio stations in Vietnam and foreign investment in the electronic media is not allowed.

With its reach and accessibility there is no doubt that The Voice of Vietnam plays an important role in disseminating essential information (such as weather reports or health messages) to far-flung parts of Vietnam. However as an institution, The Voice of Vietnam is staid and conservative with the majority of staff over 40 years old. In press terms it is more like Nhan Dan than Tuoi Tre, with the explicit duty to disseminate the party line and state policies.

Anecdotal evidence suggests that Radio The Voice of Vietnam attracts listeners with music and sport, but fails to win much of an audience for its talk-based programming. The editorial straitjacket imposed on The Voice of Vietnam means that international shortwave transmissions in Vietnamese (and to a lesser extent French and English) remain a crucial source of information. The BBC's Vietnamese service is the most widely listened to, provoking both public admiration and official ire for its series of extended interviews with dissident journalist Bui Tin, former editor of Quan Doi Nhan Dan-broadcast after he went to Paris in 1990. The French service RFI and Voice of America also attract strong audiences, as did the Vietnamese Service of Radio Australia until its signal strength was severely compromised by 1997 federal government cuts which shut down Radio Australia's Darwin transmitters. More recently the Washington-based Radio Free Asia has begun Vietnamese language broadcasts, provoking repeated tirades in Nhan Dan and other newspapers.

Abusing modern broadcasting technologies under the pretext of 'freedom' and 'democracy', a handful of hostile forces in the United States have been pursuing a plan of 'peaceful evolution' in an attempt to interfere in other countries' internal affairs, destabilise and eventually overthrow political regimes out of their favour...[they] intentionally use information and cultural means as an invasive instrument [and] persist in realising their scheme cooked up carefully for heinous purposes (Nhan Dan, 22 February 1997). 
By contrast to the Voice of Vietnam, Vietnam Television (VTV) has been more innovative in its programming. For example its student quiz show SV96 was a hit with young viewers, even though it was loaded with heavy handed moral messages. For example, competing university teams were asked to improvise a skit on the theme of countering social evils, so that young viewers would be warned away from such vices as gambling, alcohol and pornography. VTV also has the advantage of being able to rebroadcast high quality (or at least slick) foreign programming, which can vary from re-runs of such dated Hollywood dramas as Charlies Angels, to recent Australian productions like Blue Heelers or the hit Taiwanese series The Judge, about a Chinese mandarin who dispensed justice with a fair but iron hand. VTV also wins huge audiences for its sport broadcasts, especially live transmissions of major soccer matches, which draws about half the population. In the middle of the night, across Vietnam, neighbours crowd around shared television sets out on the pavement to escape the oppressive July heat, watching matches half way around the world.

These broadcasts are funded by advertising or, more correctly sponsorship. An advertising agency will negotiate to buy the rights to a foreign show, or sports telecast, and will then provide the programming to VTV in exchange for the right to sell the advertising spots around the broadcast. (Most soccer telecasts in Vietnam are sponsored by Dunhill for example.) The strict legality of such arrangements remains murky and the Communist Party has explicitly ruled out direct foreign investment in television (much to the frustration of Australia's Mr Packer and Mr Murdoch, who invested large sums of money to build goodwill with VTV).

While VTV has adapted its general programming to appeal to audience tastes, there is still a heavy dose of dour war films in the programming mix and VTV's news broadcasts remain clumsy and stilted. Domestic news bulletins consist almost entirely of an announcer's script-over vision of official handshakes and greetings. Foreign organisations working in Vietnam find that it is relatively easy to get coverage of their activities on an evening news bulletin by 'inviting' a news crew to cover an event and offering to pay them for their trouble. (In fact envelope journalism, where lunch money or taxi money is placed in an envelope in the press kit, is common in all media in Vietnam.)

The advent of satellite television has allowed VTV to re-broadcast items of international news recorded from such sources as $C N N$ and the $A B C$, 


\section{Losing control}

but strict editorial judgments are made about its suitability. Satellite dishes are not widespread in Vietnam, and the Communist Party is keen to keep it that way, concerned that foreign TV could undermine its efforts to shape the political and cultural values of Vietnamese citizens. Under a decree issued in late 1996 only senior party, government and state officials, media organisations, sections of the security apparatus and up-market hotels are authorised to receive satellite broadcasts.

\section{The Internet-taking the slow lane down the information superhighway}

In December 1997, after years of procrastination and debate, Vietnam finally allowed computer users to gain access to the Internet. The first reason for the delay was Communist Party concerns that the Internet would be a source of counter-revolutionary information and propaganda generated by exiled Vietnamese groups deeply antagonistic to the Hanoi regime. And like governments elsewhere around the world, Hanoi was also worried about Internet pornography. While the issues were debated, teams of Vietnamese officials were despatched to Singapore and China, to study tactics in building firewalls and monitoring online content. The reason for the delay was more prosaic; it was a question of money and who would control the anticipated income. A major bureaucratic and political tussle ensued to be finally resolved in favour of the General Department of Post and Telecommunications which has a monopoly on the provision of Internet connections through its subsidiary Vietnam Data Communications. Service costs are five to ten times higher than in other Southeast Asian countries and this has proved the key barrier to Internet use in Vietnam.

At the end of 1998, there were an estimated 400,000 computers in use in Vietnam, but only about 15,000 Internet subscribers. Around half the subscribers were foreigners and a fifth were government ministries or other state agencies. It is believed that only 5 per cent of Internet subscribers are private citizens. Internet services can also be frustrating for users in Vietnam. For example, firewalls make it impossible to use RealAudio to access radio broadcasts via the Internet.

The Vietnamese authorities are attempting to use the Internet for their own benefit. For example Nhan Dan has established its own website (www.nhandan.org.vn) as has the Vietnam News Agency. Vietnam 
Airlines and the Vietnam Tourism Authority have also established a presence on the net, but it is unlikely that critical websites will proliferate, as any organisation or individual wishing to provide Internet content must first be licensed to do so by the Interior Ministry. The Ministry's attitude towards the Internet is summed up by its actions in shutting down a cyber cafe in Ho Chi Minh City, because foreign backpackers were allegedly sending unsavoury messages to their friends back home. Outside Vietnam, dissident groups critical of Hanoi are enthusiastic users of the Internet (see for example the California-based Vietnam Insight, www.vinsight.org and the Paris-based Free Vietnam Alliance www.fva.org), and even before Vietnam connected to the Internet, when only limited email exchange was available, some critical messages did get through. 'The Saigonese', an acerbic Ho Chi Minh City-based critic, sent detailed postings which revealed what he claimed were the past misdeeds of leading party figures.

\section{Bitter tea: Vietnam and the foreign media}

Foreign journalists working in Vietnam are expected to engage in a process of mutual cooperation with the Press and Information Department of the Ministry of Foreign Affairs. In essence this means adhering to an elaborate and, at times, opaque set of controls.

The first condition is that foreign media can only set up bureaux in Hanoi and not in the larger, more open, southern business capital Ho Chi Minh City. Second, reporters need a permit for any professional travel outside the capital. The permit must be applied for well in advance and requires approval from local officials in the province to be visited as well as authorities in Hanoi.

All foreign correspondents in Vietnam must also hire via the Ministry of Foreign Affairs, a press assistant, who is supposed to act as interpreter, guide and monitor whenever the correspondent undertakes any journalistic activity. Each Saturday afternoon the press assistants attend a weekly briefing at the Ministry and may be singled out and chastised over the activities or reporting of 'their' correspondent. Press assistants, and other Vietnamese nationals who assist foreign journalists, may also find themselves subject to questioning by security officials from the Interior Ministry. At worst this turns the correspondent's assistant into a spy-at best it put the assistant in the invidious position of having to serve two masters. 
The frustrations of these controls were acutely felt in 1997 by foreign reporters attempting to cover the unrest that rocked the province of Thai Binh, just $60 \mathrm{~km}$ from Hanoi. All formal requests for permission to travel to Thai Binh were refused. One foreign journalist based in Hanoi who did break the government ban was spotted and immediately 'invited' into the Press Department 'to drink tea' - a euphemism for being reprimanded and officially warned. All correspondents rely on the Press Department for assistance in the six-monthly renewal of their visas, otherwise they can be forced to leave the country when their current visa expires. This happened in 1996, when Adam Schwarz, correspondent for the Far Eastern Economic Review, was effectively expelled from Vietnam. And for correspondents there is also the problem of trying not to expose a Vietnamese bureau assistant to unacceptable risks. While a foreign journalists may be let off with a warning a local assistant could find their chances to study denied, their application to travel overseas stalled or, at worst, end up in jail for revealing state secrets.

Correspondents also rely on the Press Department for assistance in obtaining official interviews and travel permits, a power which can be turned against those who refuse to 'cooperate'. Behind that power lies Article 13 of the Regulations on Press and Information Activities of Foreign Journalists, Offices and Organisations in Vietnam, which states 'In order to carry out journalistic activities mentioned in the Regulations, the resident journalists must send their requests on a case-by-case basis to the Ministry of Foreign Affairs at least 5 days in advance and are not allowed to carry out those activities before the issuance of the 'Press Permit' by the Ministry of Foreign Affairs'.

Taken literally, Regulation 13 means a foreign journalist should request written permission from the Foreign Ministry five days before picking up the telephone to their own embassy. The Press Department insists it is 'flexible', but flexibility means the regulation is arbitrary. Like so many Vietnamese laws, the regulations governing foreign media activities are broad-brush provisions that can be applied to prevent a journalist from engaging in any activity that any official body at any time decides is offlimits. Sensitive meetings between foreign journalists and dissidents are often observed by secret police who appear to make themselves obvious as a form of intimidation. At other times appointments are cancelled at short notice, presumably because the people involved have been warned. 
The government is also concerned that foreign correspondents could glean sensitive information from Vietnam's new crop of young, enthusiastic and increasingly critical domestic journalists. In order to address this issue the government introduced new regulations in September 1997 explicitly banning Vietnamese journalists from providing their foreign colleagues with information, photographs or articles without prior approval from the government. The interaction between local and foreign media was already sadly limited because foreign journalists are excluded from most domestic media conferences organised by government departments or agencies in Vietnam. The Communist Party clearly wants to limit ideas or information flowing in either direction. In August 1997, the head of the Ho Chi Minh Political Academy, politburo member Nguyen Duc Binh, launched a blistering attack on western influence on the Vietnamese media, saying such 'cultural and political trespassing...destroys the boundaries of social order and national sovereignty in press and information activities' (Nhan Dan, 26 August 1997). There also appears to be an unofficial ban on Vietnamese journalists going to the United States to study, though countries like Australia or the United Kingdom still appear to be acceptable destinations.

Despite its role in regulating and reprimanding foreign journalists, the Foreign Ministry must still be regarded as one of the most open and progressive of all Vietnamese government agencies and the Ministry's Press and Information Department seems to respond to other more security-minded sections of the state apparatus, particularly the Interior Ministry. With the important exception of television stories, the Press Department has no means of exerting direct control or censorship over the material that foreign journalists file from Vietnam. Radio reports, for example, are generally filed directly over a standard telephone line and without rigorous monitoring.

Television is an exception. Any video or film footage shot in Vietnam must be cleared by the Foreign Ministry prior to its export or transmission via satellite. Courier companies will refuse to carry a tape that has not been cleared. Vietnam Television will refuse access to satellite ground station facilities unless the appropriate clearances are obtained first. When the subject of filming is controversial, it has usually been shot without a permit and the journalist must find an unofficial route to get it out of the country. 
In the print media, particularly US citizens working for influential regional magazines like the Far Eastern Economic Review or the Asian edition of TIME were closely scrutinised. Far Eastern Economic Review and TIME appear once a week; the index can be easily checked for stories on Vietnam and officials know that articles are easily photocopied and passed around. A government agency has the monopoly on the import of foreign publications to Vietnam and Far Eastern Economic Review and TIME are routinely censored, with paragraphs or even entire stories blacked out before magazines are distributed domestically. Journalists and editors are routinely called in to 'drink tea' and forced to mount a line-by-line defence of their copy.

In the late 1980s and early 1990s many western journalists who arrived in Hanoi to open up offices on behalf of foreign news organisations harboured a considerable residue of sympathy for Vietnam as a result of the war years and the subsequent economic embargo. Their initial reporting of the country focused on business opportunities for foreign investors, and on the nation's own attempts to reform and rebuild its economy and society. Much of this coverage was broadly optimistic in tone, supportive of the reform process and enthusiastic about the nation's achievements.

By late 1997 the mood had soured dramatically. The advances made in journalistic and editorial independence in the Vietnamese media in the late 1980s had been reversed and controls on the activities of both the foreign and domestic press had been tightened. With a slowdown in investment, Vietnam was producing few positive news stories and with inward-looking Communist Party policies, the country was producing very few stories at all, leaving foreign news organisations with flagging enthusiasm for the frustrating daily battle against the bureaucratic restrictions. In addition, the restrictions hinder the accurate and timely reporting of real problems which can, ironically, lead to a more exaggerated version of the story appearing in the foreign press.

Vietnamese officials repeatedly stress that they want foreign journalists to 'understand Vietnam' but the real intention of existing regulations is exactly the opposite; the aim is to corral correspondents into acceptable corners where they can cause minimal embarrassment to the regime. When foreign journalists are summoned to the Press Department for criticism sessions, it is usually because their understanding of what is going on around them is too acute. It is knowledge, rather than ignorance, which 
generally causes offence. Older revolutionaries may be gradually moving on but their technocratic younger comrades, trained in the former Soviet Union, Cuba or East Germany, are not necessarily any more sympathetic to notions of press freedom.

The Communist Party was deeply disturbed by the collapse of European Communism-more recently it watched with alarm as the apparently enduring edifice of Soeharto's New Order crumbled in its own neighbourhood. The Communist Party has attempted to shore up its leading role in society by reinvigorating its nationalist credentials (and allowing its rather tattered Marxism to fade into the background) and, above all, by delivering the prosperity and economic stability that it knows the population craves. Yet by unleashing the creative and destructive power of the market, the Communist Party has created a new set of social forces that it cannot hope to control. Rapid growth creates a yawning gap between rich and poor and between city and country. It accelerates the dramatic demographic migration from rural to urban areas and encourages a psychological shift from austerity to consumerism. Established notions of solidarity are under pressure from a new individualism; the lure of easy wealth corrupts the values of public service and altruism; commercial development puts new pressure on limited resources like land and water. In short, new contours of conflict are emerging in Vietnam, as the society undergoes fundamental and rapid change. Yet the Communist Party has a limited repertoire for dealing with conflict; and when confronted by critics, usually reaches for the trusty tools of repression.

Recent protests in north and south Vietnam are a sharp reminder that Vietnam's veneer of political stability is brittle, but the Communist Party's dogged determination to project an outward image of harmony precludes it from engaging in frank and constructive exchanges, let alone allowing others outside its ranks to conduct such exchanges through the media. The pressures building up in Vietnamese society are still a long way from boiling point, but in its determination to keep the lid firmly on the pot, the Communist Party is only helping to speed up the process. 